\title{
SPATIAL DATABASE DEVELOPMENT FOR OIL SPILLS POLLUTION AFFECTING WATER QUALITY SYSTEM IN NIGER DELTA
}

\author{
H. A. Umar ${ }^{1,2}$, M. F. Abdul Khanan²,* A. Ahmad ${ }^{2}$, M. J. Sani', M.Z. Abd. Rahman², A. Abdul Rahman ${ }^{2}$, \\ ${ }^{1}$ Department of Environmental Sciences, Faculty of Science, Federal University Dutse, P.M.B 7156, Dutse, Nigeria - H.A.U.- \\ abdulhafizamin@yahoo.com \\ ${ }^{2}$ Department of Geoformation, Faculty of Built Environment and Surveying, Universiti Teknologi Malaysia, 81310, Johor Bahru, \\ Malaysia - H.A.U.- abdulhafizamin@yahoo.com, M.F.A.K.- mdfaisal@utm.my, A.A.- anuarahmad@utm.my, M.J.S- \\ mjsani71@gmail.com, M.Z.A.R-mdzulkarnain@utm.my, A.A.R. - alias@utm.my
}

KEY WORDS: Niger Delta, oil spill, groundwater, Kernel density, entity relationship

\begin{abstract}
:
The effects of oil spills in the Niger Delta has caused unending menace to the quality of drinking water in most wells and boreholes of the area as most of the wells are shallow and are susceptible to contamination due to the nature of its Geology. The aim of this paper is to develop a database on how oil spills affects water quality which is one of the most crucial resources in the Niger Delta. The study uses existing oil spills data to show the areas and extent of oil pollution in the Niger Delta. Geospatial analysis was used to design an oil spill data base comprising the logical, physical, and conceptual data base design. Visio was used for the design of the entity relationship (ER) diagram of the study. The Kernel density and Getis-Ord G* statistic were used in GIS to map the oil spill areas in the region. Results of spatial spill distribution from the Kernel density and Getis-Ord G* statistic revealed that three states of the Niger Delta namely, Bayelsa, Rivers, and Delta states are the hottest spots for oil spill occurrences and distribution. The ER chart showed the relationships between the pollution sources, their pathways, and the receptors. The ER diagram developed could be of significance to environmentalists and other stakeholders in understanding the processes through which contaminants get to the various compartments of the earth system.
\end{abstract}

\section{INTRODUCTION}

The manifestation of imbalance between demand and supply of water resources due to water pollution from points to nonpoints sources are the most pronounced factors affecting water resources quality in most developing countries including Nigeria (Hiscock and Grischek., 2002; Nicolini et al., 2011; Ray and Shamrukh., 2011; Olorunfemi et al., 2010). Water is one of the most vital resources to living creatures. It is naturally ubiquitous; however, its access is becoming practically difficult to many communities of the Niger Delta due to surface and groundwater contamination. Water pollution has rendered many societies water stressed, even though the water is physically available (Mustafa et al., 2014; Ray and Shamrukh., 2011). Naturally, Niger delta is a wetland area and therefore, the health of the environment as well as the people's lives are intertwined with the health of the hydrological system (Ipingbemi, 2009). Delta ecosystem encompasses the food, water and cultural identity of many local communities, therefore, rivers and streams plays a pivotal role as both are used for drinking, bathing, washing, and fishing in the area.

The impacts of oil spills are seen in the quality of water resources of the Niger Delta, while the un-dissolving contaminants can be visible especially for surface water, the dangers posed by the dissolved contaminants especially heavy metals can be fatal. The impacts of oil spill from artisanal refining on the Oturuba River ecosystem in the Niger Delta was examined using active river bottom sediment (Ezekwe and Utong, 2017). The study revealed for both heavy metals and hydrocarbons, elevated concentrations in ranges above the recommended sediment quality guidelines. The concentrations exceeded the threshold and the probable effect levels making Oturuba Creek one of the most polluted coastal river systems in the world (Ezekwe and Utong, 2017). The susceptibility to high risk diseases of communities making use of water from such rivers for domestic purposes is extremely high. Nwaichi and Ntorgbo (2016) investigated the polycyclic aromatic hydrocarbons (PAHs) levels 16 in 30 edible tissues of fishes and seafood collected from Sime, Kporghor and Iko coastal waters of Niger Delta. PAHs' gas chromatographic analysis showed that the levels of the observed mean in the samples was of the range below detection limit (BD) of analytical to 22.400 $\pm 0.050 \mu \mathrm{g} \mathrm{kg}-1$ wet wt.

Moreover, the consequences of prolonged exposure to toxic compounds in contaminated waters can lead to cancer, birth deformities among humans and other organisms (Salem, 2001). The impacts of oil spill on the socio-economic activities and the environments in some communities of the Niger Delta area was assessed by Ipingbemi (2009). Water samples from five locations in Burutu local government area of Delta State were collected in order to determine the $\mathrm{pH}$ value and the total hydrocarbon content (THC) of the water. The result indicates that in three communities the level of total hydrocarbon concentrations (THC) exceeded both WHO limit of $1 \mathrm{ppm}$ and control site with concentration of about 40,000ppm (Ipingbemi, 2009). Abdus-salam and Adekola (2010) examined the water qualities for chemical parameters and heavy metals from five different communities sharing the same river in Ilaje local government area of Ondo state. Results showed that waters from the source were found to be generally unsafe for domestic and agricultural use, due to pollution from various sources including bedrock modifications, oil spillage, and boat exhaust.

Furthermore, Nduka and Orisakwe (2011) examined the concentration of heavy metals and chemical properties of surface water utilized by indigenous communities in Bayelsa, 
Delta, and Rivers states. Water samples were collected at irregular intervals to account for the major differences in the river properties that may occur on a daily basis. Analysis of results revealed that the surface waters in Delta and Rivers state were more contaminated than those in Bayelsa due to the increase in metal concentration which affects the salinity of the water and its $\mathrm{PH}$ levels. Oil contamination of creeks, rivers, and ground waters in Ogoniland, Nigeria was assessed by Lindén and Pålsson (2013). The analysis of the samples indicated remarkable percentage of extractable petroleum hydrocarbons (EPH) in most of the waters. According to the United Nations Environmental programme as reported by Yakubu (2017), these high concentrations of extractable petroleum hydrocarbon can cause migration of different species of animals and render water unfit for human consumption.

Water is very vital to our existence and therefore any unforeseen breakdown of existing water resources as a crucial infrastructure will lead to a very devastating situation. This situation is also being exacerbated by the facts that, the same infrastructure will be needed to serve as mitigation in cushioning the effect of the disaster. In essence, the pipe borne water, boreholes and hand-dug wells are important in averting and mitigating the upsurge of water borne diseases especially in a densely populated Niger Delta area (Kwasinski, 2014; Chang et al. 2014; Mittelstadt et al. 2015; Faturechi \& Miller-Hooks 2015). Several researches attest to the fact that in many developed nations achievements has been made in establishing water resources infrastructure as an integral part of pollution control. However, the situation in third world countries like Nigeria are contrary (Toroczkai \& Eubank 2005; Macal \& North 2006; Pederson et al. 2006; Yusta et al. 2011; Birkett \& Jetmarova 2014; Trucco \& Petrenj 2015; Ouyang, 2015).

An indelible history of emergency situations in Nigeria according to Olowu (2010) shows the pattern of how poor and uncoordinated approaches in disaster handling causes lots of terrible situations. Looking at importance attached to the water quality, emergency and rescue personnel should find a proper way to take an immediate action in case of water resources contamination from both natural and anthropogenic oil spills pollution (Onwuka, Ikekpeazu \& Muo 2015; Hochrainer et al, 2015). Despite significant importance attached to the geospatial information as an integral part of sustainable socio-economic development, location-base real time component of disaster management is lacking in Nigeria (Kufoniyi and Akinyede, 2004; Obi, 2006; Manfré et al. 2012; Kerle \& Kufoniyi 2005).

Past studies related to disaster management in Nigeria, including GIS based disaster management related, failed to established the required link between disaster management and critical infrastructure including water resources. The study conducted by Egberongbe et al. (2006), Adedoyin and Olanrewaju (2006), Agbo (2007), Olowu (2010), Samuel et al., (2014) and Elias and Omojola (2015) authenticate this fact. The importance of geospatial database on a water resources as a crucial infrastructure couple with other spatial and non-spatial information on other infrastructure will serves as a good foundation for effective and efficient way to curtailed any unforeseen circumstances during disaster outbreak (Altan and Kemper, 2010; Zevenbergen, Kerle \& Tuladhar, 2013). The database serves as a very important yardstick for cushioning the effect of water resources infrastructural decay. The main purpose is to educate and inform policy makers on environments and other stake holders on the need to protects water resources from oil spills contamination in the Niger Delta. The study uses spatial analysis to show the pattern of pollution migration pathways from the sources to the receptors.

\section{DESCRIPTION OF THE STUDY AREA}

The area considered for this study is the Niger Delta region of Nigeria. The oil-rich Niger Delta is located on latitude $4010^{\prime}$ to $6020^{\prime}$ 'north and longitude $2035^{\prime}$ ' east of the equator projecting towards the Gulf of Guinea on the Atlantic coast of West Africa. It is also the second world largest delta having a coastline of about $450 \mathrm{~km}$ that ends at the Imo River's entrance (Awosika, 1995). It stretches from the coast of Ondo, Delta, Bayelsa, Rivers, Akwaibom to Cross Rivers state (Imoobe and Iroro, 2009). Covering about $70,000 \mathrm{~km}^{2}$ wetland, the region has been described to be among the top ten wetlands and deltaic ecosystems in the world (Achebe etal., 2012; Hooper etal., 2002; Phil-Eze and Okoro, 2009).

Stagnant swamp covers approximately $8600 \mathrm{~km}^{2}$, while rivers, creeks, and estuaries cover about $2,370 \mathrm{~km}^{2}$. The mangrove swamp which is the largest swamp in Africa spans about 1900 $\mathrm{km}^{2}$ (Awosika, 1995). There are myriads of species of plants and animals in the Niger-delta, including fruits, timber species, medicinal plants, palm trees, nuts, seeds, tannis, edible vegetables, grass and bamboos, while the different species of fauna inhabiting the Niger-delta region includes monkeys, mongoose, squirrels, antelopes, otters, reptiles as well as many species of insects, birds; and invertebrates (World Bank, 1995; Ebeku, 2005; IUCN, 1994; Kuenzer etal., 2014). States that formed Niger Delta includes Ondo, Edo, Delta, Rivers, Bayelsa, Cross River, Imo, Abia and Akwaibom. Figure 1 is a map of the Niger Delta showing its 9 states.

The climatic condition in the Niger Delta region has been categorised as wet equatorial climate and its characterised by huge cloud cover and less sun shine hours which resulted in to damp weather condition in most part of the year. Though, the cloud cover and the dampish nature of the atmospheric condition moderated the temperature to about $28^{\circ} \mathrm{C}$ around August and $34^{\circ} \mathrm{C}$ or even higher around February and March. The annual rainfall in the Niger Delta is about $2,500 \mathrm{~mm}$ spanning between April to December with break around January until March (Osuji and Nwoye, 2007). This is however, due to variation in the climatic condition which is more favourable in the southern part of the country with about 9 month of rainfall and less shower in the North with only four months (Eludoyin etal., 2014).

The discovery of oil and gas in the Niger Delta has tremendously changes the polity. Hitherto to the oil discovery, the mainstay of Nigeria's economy was exportation of agricultural produce such as cotton, cocoa and groundnut. However, as more crude oil reserves were discovered, there was a shift of paradigm from agricultural produce to crude oil exportation. As a result, large percentage of Nigeria's export earnings came from oil exploration (Ndoms, 2005). 


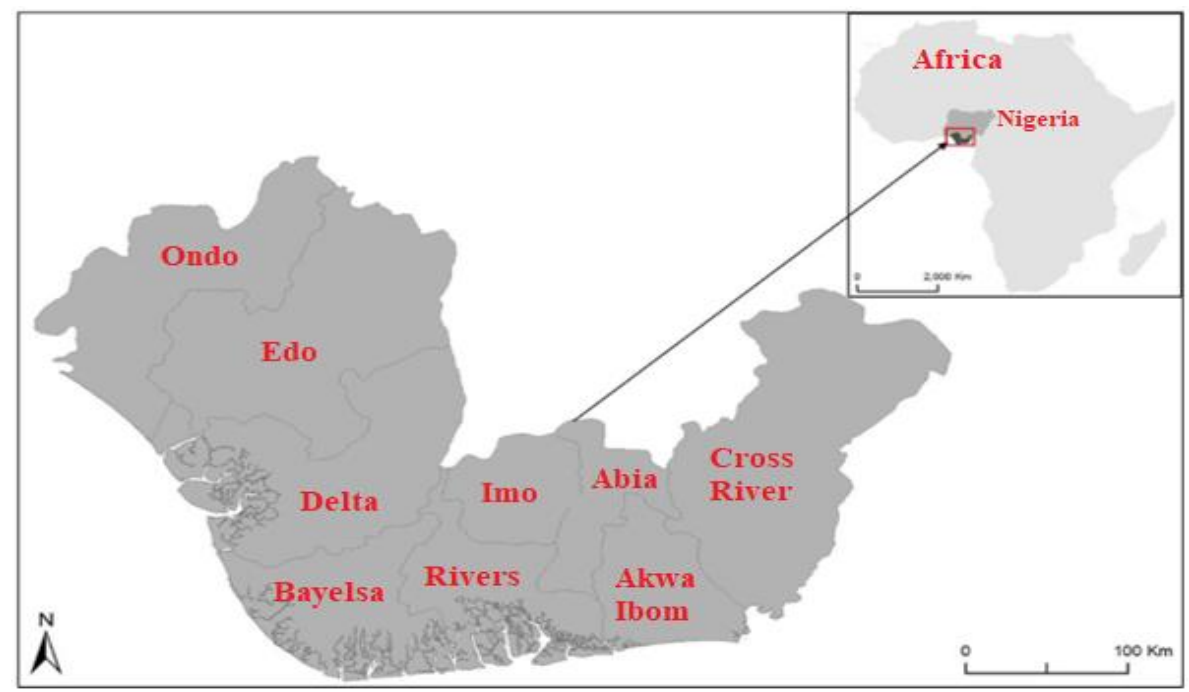

Figure 1. Map of Nigeria showing the nine states of the Niger Delta.

\section{MATERIAL AND METHODS}

This study considers water quality resources as a critical infrastructure in the Niger Delta region. It involves the design pattern of database for the purpose of studying how oil spills affect water quality which is one of the most crucial resources in the Niger Delta region. The design pattern includes the oil facility, oil facility units, oil pipelines, oil spills, roads, rivers and streams, some selected boreholes and hand-dug wells as well as their location settlements including schools and hospitals. These major infrastructures were successfully incorporated into the database design. However, the selection of this class of water resources infrastructure was purely based on data availability. Additionally, issues related to data acquisition and storage necessitate a lot of extensive work in building the database for the study. Secondary data were also obtained from the ministry of water resource. Oil spills data covering the entire Niger Delta from 2007- 2015 were obtained from both NOSDRA and Shell PLC, oil pipeline from NOSDRA and extensive search on internets and other written sources were judiciously used on this study. The acquired data were successfully structured in to spatial databases based on dual purposes of existing inventory of critical water resources infrastructure in the area and of being utilized in the wakes of oil spills pollution disaster. Database creation encompasses the design phase and the actual creation of the databases. The spatial distribution of pipeline oil spills has been depicted in Figure 2

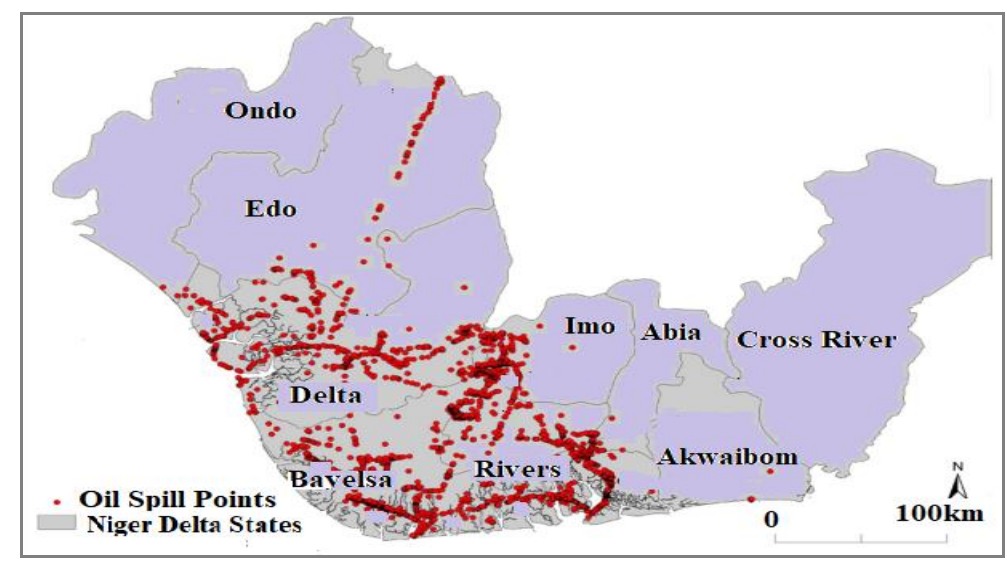

Figure 2. Spatial distribution of pipeline oil spills in the Niger Delta from 2007 to 2015.

\subsection{Getis-Ord G* statistic and Kernel Density Map}

This study employed the application of kernel density estimation (KDE) and Getis Ord statistic in oil spills hot spot detection. Even though, the application of Kernel density estimation was developed purposely for epidemiological studies, it has been successfully extended to areas of transport, environment and other related fields. This approach has been utilized by several researchers in identifying significant hotspots in spatial data (Benedek etal., 2016; Chicas etal., 2016; Mahboubi etal., 2015). The methods is suitable for this study because it can be appropriate for point data sets as well (Kuo etal., 2013; Xie and Yan, 2013). Protection of both surface and groundwater is crucial in order to have a clean and portable water that would be used for several purposes. This study therefore, collected oil spills data from National Oil Spill Detection and Response Agency (NOSDRA) for the period of 9 years in order to map out areas that are highly polluted, moderately polluted and less polluted. The data has been utilized in producing Kernel density hotspot map and Getis-ord $\mathrm{G}^{*}$ statistical map. The maps show how oil spills impacted most of the states in the region. 


\section{OIL SPILLS POLLUTION IN THE NIGER DELTA}

Environmental pollution from oil exploration and exploitation has plagued the Niger Delta region for over five decades since oil discovery in the area. This was compounded by the more recent activities of bunkering and artisanal crude oil refining, worsening the socio-economic developments in the area and increasing health hazards (Kponee etal., 2015). Osuji and Onojake (2004) reported damages to the fragile mangrove forest, threats to rare species of fishes, birds, turtles, and primates, increased poverty, reduced life expectancy, and loss of livelihoods of the people of the Niger Delta area. Oil spills in the Niger delta adversely affects the physical, chemical and biological properties of soil which subsequently resulted in food shortages due to reduction of nutrient contents of the soil (Ogboghodo and Iruaga, 2004).

According to Anejionu et al., (2015), over 10,000 incidences of pipeline explosions and oil spills has been reported with more than 350 billion cubic meter of gas flared in the Niger Delta area in the last 14 years. In addition, the unprecedented level of environmental destruction in the region has caused a wide range of terrestrial and marine ecosystem degradation leading to loss of agricultural lands and aquatic lives thereby affecting people's livelihoods (Chima etal., 2013; Yakubu, 2017).

There are numerous sources of oil spills in the Niger Delta area which includes: pipeline interdiction; pipeline explosion and spills occurring as a result of blow out, as well as improper disposal of drilling waste from oil exploration and exploitation activities (Harcourt, 2014). Oil spills from the aforementioned sources have been reported over the past decades since the first oil spill incidence at Araromi in the present Ondo state in the year 1908 (Tolulope, 2004). Later on, in the year 1979, 570,000 barrels of crude oil was spilled at the Forcados Tank six terminal causing pollution of the aquatic environment and the surrounding swamp of the Forcados estuary (Ukoli, 2005).

Subsequently, a blowout which occur at Funiwa Number five well in 1980 spilled an estimated 421,000 barrels of crude oil into the ocean (Tolulope, 2004) destroying 836 acres of mangrove forest along six miles off the coast (Kadafa, 2012).

Some other minor spills reported include a spill of 5,000 barrels of crude oil which occurred along Ogada Brass 24 pipeline in Oshika village, Rivers state in 1983 polluting the lakes and swamp areas of the community; oil spill from a pipeline where 24,000 barrels of crude oil polluted the fresh water swamp forest and brackish water mangrove swamp at Ogada Brass near Etiama Nembe community in the year 1995 (Kadafa, 2012). Furthermore, Egberongbe and Badejo (2006) reported between 1976 and 1996, a total of 4,647 incidents of oil spills resulted in an approximate $2,369,470$ barrels of oil spilled into the environment in the Niger Delta. Oil spills in the Niger Delta affected all the compartment of the earth, including the atmosphere, biosphere, hydrosphere and lithosphere

\subsection{Hotspot Analysis}

Hotspot Analysis uses vectors to identify locations of statistically significant hot spots and cold spots in a data by aggregating points of occurrence into polygons or converging points that are in proximity to one another based on a calculated distance. The analysis groups feature when similar high (hot) or low (cold) values are found in a cluster. The polygons usually represent administration boundaries or a custom grid structure. Figure 3 below is a map of hotspots and cold spots produced using Gi_Bin statistical tool to show how oil spills wreak havoc to many Niger Delta's states, polluting the environment and destroying the entire ecosystem.

From the map it is clearly shown that areas around Rivers, Delta and Bayelsa were severely impacted by the spill during the 2007-2015 period and as such towns and villages located within these areas suffers more severely. From the interpretation of the map, the Gi_Bin field identifies statistically significant hot and cold spots. therefore, spills with cold spot $99 \%$ confidence is indicating the least impacted areas, followed by cold spot $95 \%$ and $90 \%$ respectively, while areas that are not impacted are refers to as "not significant" indicating clustering for feature zero. The hot spot $90 \%$ confidence shows areas of moderately impacted, followed by $95 \%$ showing areas of most impacted while $99 \%$ shows areas of highly impacted.

In the general application of Gi_Bin feature in the $+/-3$ bins (features with a Gi_Binvalue of either +3 or -3 ) are statistically significant at the 99 percent confidence level; features in the $+/$ 2 bins reflect a 95 percent confidence level; features in the $+/-1$ bins reflect a 90 percent confidence level; and the clustering for features with 0 for the Gi_Bin field is not statistically significant. This has been shown in Table 4.0 below.

\begin{tabular}{|c|lc|l|}
\hline G_Bin Value & \multicolumn{2}{|l|}{ G_Bin -Level of confidence } & Statistical Analysis \\
\hline-3 & Cold spot & $99 \%$ & $+/-3$ bins are significant at 99\% Confidence level \\
\hline-2 & Cold spot & $95 \%$ & $+/-2$ bins reflect a $95 \%$ Confidence level \\
\hline-1 & Cold spot & $90 \%$ & $+/-1$ bins reflect a $90 \%$ Confidence level \\
\hline $0-1$ & Not Significant & 0 bin field is not statistically significant \\
\hline $2-1$ & Hot spot & $90 \%$ & \\
\hline 2 & Hot spot & $95 \%$ & \\
\hline 3 & Hot spot & $99 \%$ & \multicolumn{1}{l|}{} \\
\hline
\end{tabular}

Table 4.0 Statistical Analysis of hotspot map using (Getis-Ord)

However, Kernel density hotspots map depicted in Figure 4 is a results of 9 years' oil spills that polluted many part of the Niger Delta, the map shows areas that are more clustered, moderately clustered and less clustered, indicating highly impacted areas, moderately impacted areas and less impacted areas. Areas mostly affected are Rivers, Bayelsa and Delta states. Kernel Density calculates the density of point features around each output raster cell. The method helps to precisely identify the location, spatial extent and intensity of oil spills hotspots. The density surface created can reflect the distribution of incidents against the natural geography of the area of interest, including representing the natural boundaries, such as reservoirs and lakes, or an alignment that follows a particular street in which there is a high concentration of the spill. The method is also 
The International Archives of the Photogrammetry, Remote Sensing and Spatial Information Sciences, Volume XLII-4/W16, 2019 6th International Conference on Geomatics and Geospatial Technology (GGT 2019), 1-3 October 2019, Kuala Lumpur, Malaysia

less subjective if clear guidelines are followed for the setting of of oil spills clustered which was used in producing hotspots. parameters. The procedure starts by displaying on a map point

\section{Legend}

- Cold Spot - $99 \%$ Confidence

- Cold Spot - $95 \%$ Confidence

- Cold Spot - $90 \%$ Confidence

- Not Significant

- Hot Spot - $90 \%$ Confidence

- Hot Spot - $95 \%$ Confidence

- Hot Spot - $99 \%$ Confidence

Nige_Delta_States

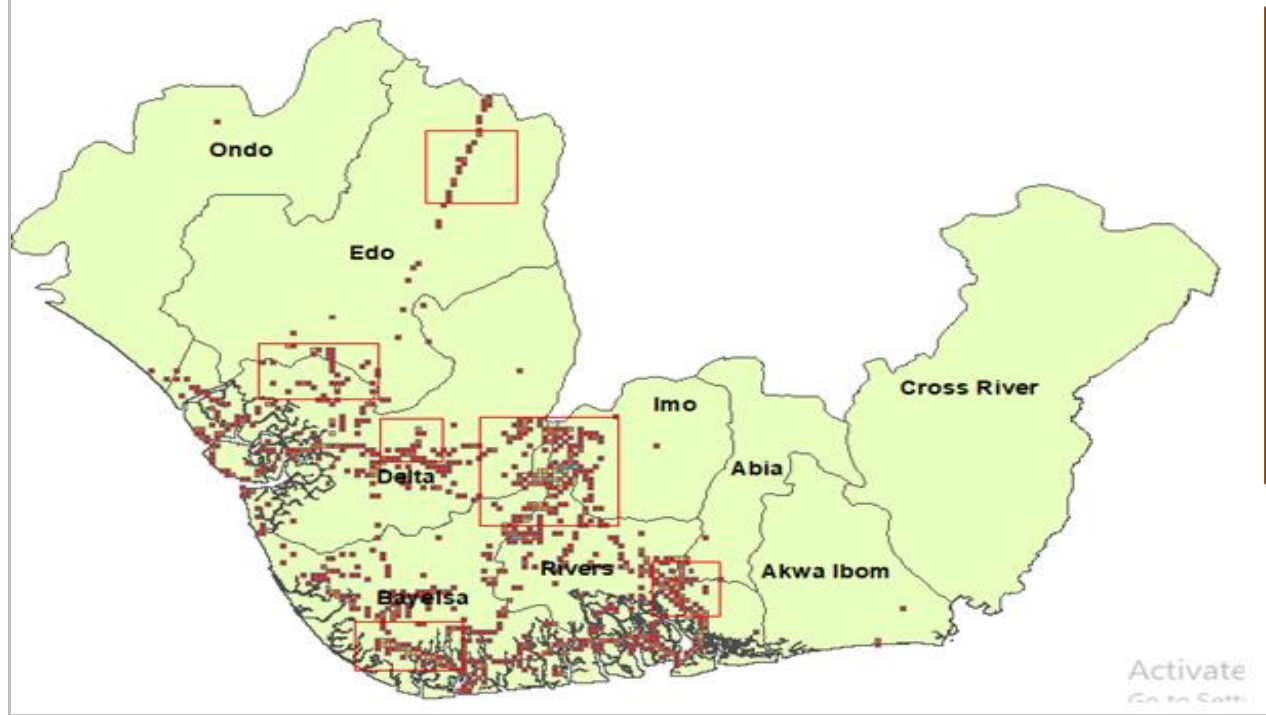

Figure 3. Getis-Ord G* statistic (Gi_Bin) showing areas that are more impacted

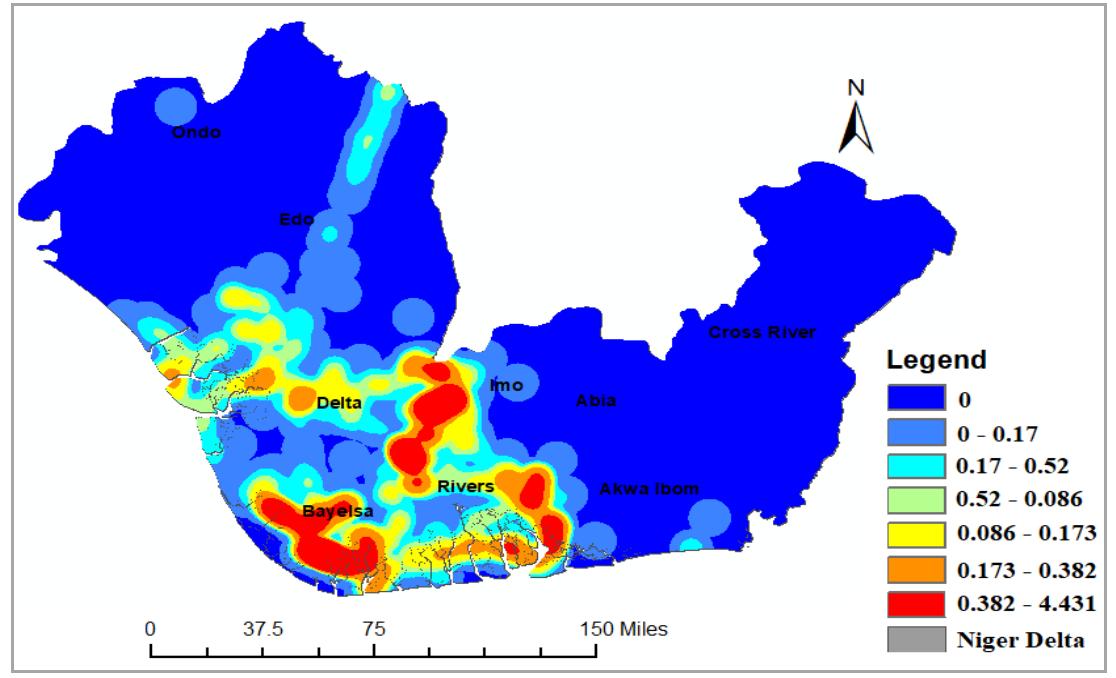

Figure 4. Oil spill hotspot map of kernel density. 
The Getis-Ord G* statistic and Kernel Density hotspot map presented in this study is meant to provide full details of how oil spills affected areas of the Niger Delta region, but not for comparism. The details would assist in understanding the hotspots and cold spots areas affected by the spills.

\subsection{Geospatial database design}

This stage, involves abstracting the geographical characteristics of interest from the real world, which often requires sound knowledge of the actual reality to be modelled. However, the real world complexity necessitates a more concise, solid and friendly representation of this complexity in actual sense (Hsiao etal, 2014; O'Sullivan and Unwin, 2014). Database design therefore, is the process of producing a detailed data model of a database. Importantly, priority should be giving to the representation or the actual reality as it is one of the most important yardstick which is also known as view of reality. The term reality here means the totality of the phenomena such as characteristics of the terrain, as it surfaces on the face of the earth, while the phenomena of interest to the application refer to as a "view" (Davidson and Moss, 2012; Getta, 1993). Similarly, due to the irregular and constantly changing nature of the realities, the real world perception is dependent solely on the observer. The real world therefore, facilitates the study of a chosen area of application by cutting down the complexity numbers considered. Furthermore, for the application of the real world model, it has to undergo a process in a database (Bern hardsen 1992). In this research, the study area total arrangement as it exist in the real world is representing the "reality", while the spatial arrangement of all the variables including oil facilities and oil pipelines in relation to various land use as well as their roles in environmental pollution is refer to as a "view" as shown in Figure 3.14.

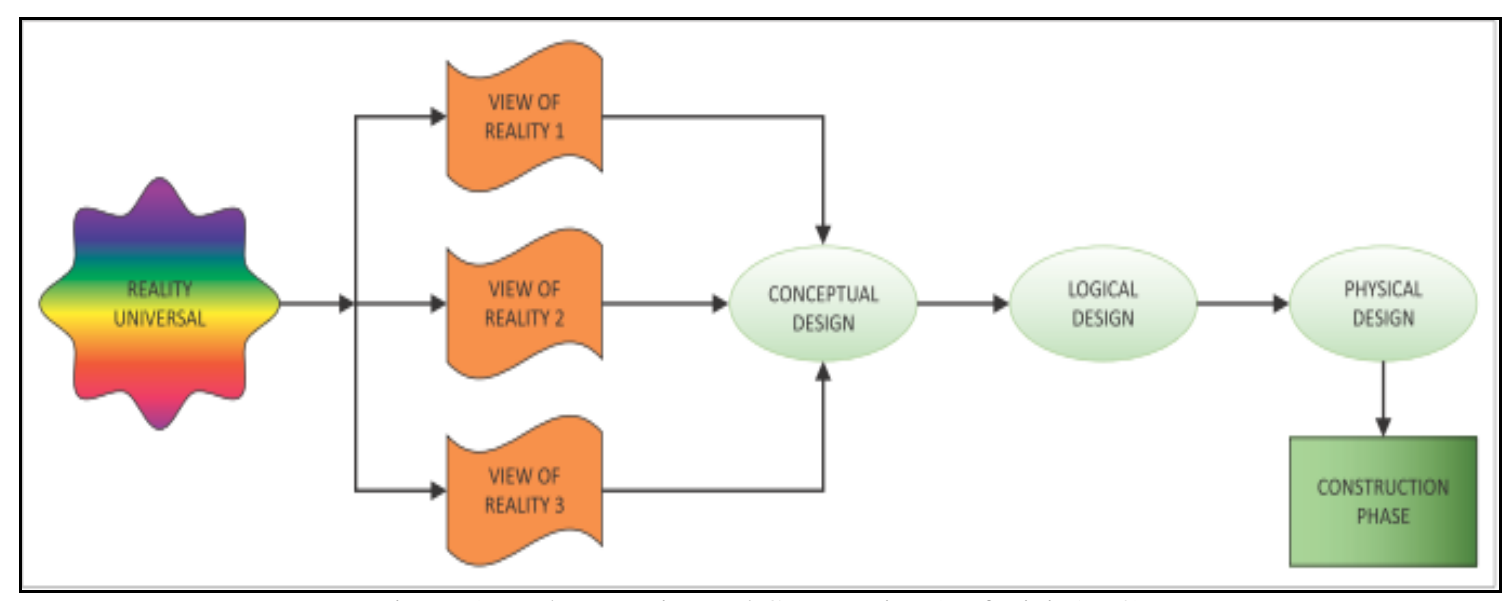

Figure 5 Database Design and Construction (Kufoniyi, 1998)

\subsection{Conceptual Design}

In a database design, GIS database developer is primarily concerned with how the data sets are viewed, free from system implementation. This entails the medium of data storage i.e. where and how the data is to be stored (Umanath and Scamell., 2014; Currim et al., 2014). The conceptual design enables the description of the object of interest and relationships, where entities are instances of entity type and relationship are instances of relationship types (Rigaux and Voisand., 2002). The human perception as a view of reality previously described has given an insight on this entity-relationship concept. Modelling or representing this human perception requires a suitable data model which gives fair representation of the features of interest so far identified. This present study adopts a vector data model which is a representation of geographic features of point, line, and area. The breakdown of the entities is:

- Line feature: oil pipelines, water pipelines and roads

- Point feature: oil facility, facility unit, hand-dug wells, boreholes, medical facility

- Area facility: land area, river area, residential area, school area

By using topological primitives of arcs and nodes, the object types representing geometric component of the application has been depicted in Figure 6. Primary data types shown in eclipseshape and the connections between them represented by arrows indicating each data or element belongs to one class. For example, oil pipelines, water pipelines and roads are line features designed with arcs that begins and terminates with end nodes and characterized by $\mathrm{x}$ and $\mathrm{y}$ coordinates.

This study employed the application of entity-relationship (ER) data model for mapping out the relationships and constraints linking the identified entities in the study. ER diagram plays a vital role in semantic information mapping of objects of interest in the database and represent an existing relationship between an object in reality and possibility of getting access to the database (Al-Masree, H.K., 2015; Bagui, S. and Earp, R., 2011; Kadivar, M., 2015; Thalheim, B., 2013). Both entities and the relationships in the study area has been identified and appropriate data model has been chosen to represent them. These entities include the oil facilities, facility units, oil pipelines, location of the spills, roads, water bodies and land, hand-dug wells and boreholes as well as clusters/residential areas. However, the data model is build using the supplied information established in the user requirement specifications. Any of the following schemes is appropriate in conceptual design, which include; Tessellation, Vector, and Object oriented. However, for the purpose of this study vector approach has been adopted in order to form a better understanding of the entity relationships. Figure 7 explains the ER diagram of the developed database. 


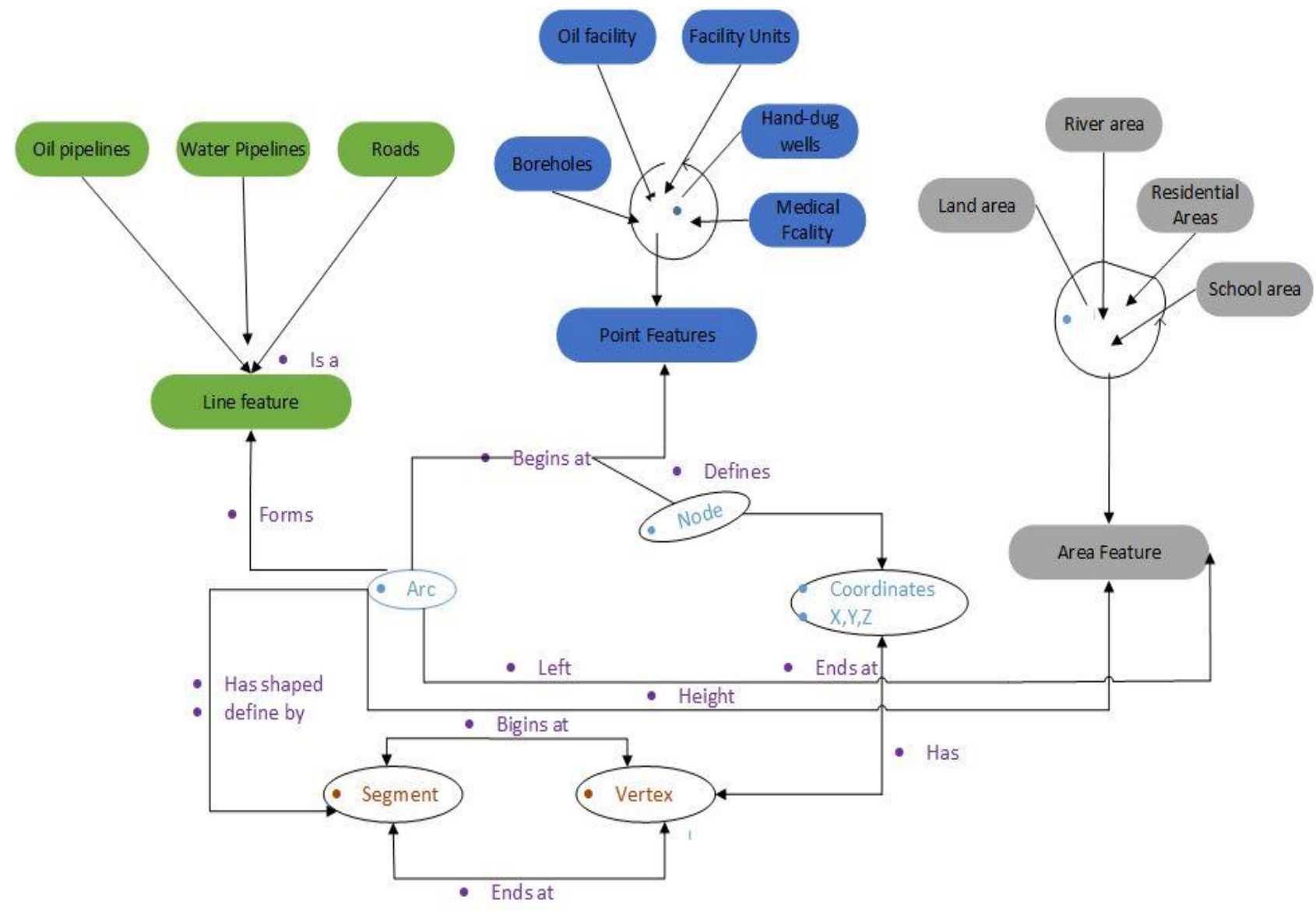

Figure 6. Spatial data model for oil spills pollution

The vector data model constituting geographic features of interest which includes point, line and area has been design to represents the applications domain of the actual reality. Decomposing the entities of interest in to a vector data model reveals the structure as (1) lines which includes Roads, oil pipelines and water pipelines, (2) Points encompassing oil facility, facility units, hand-dug wells and boreholes and (3) area feature including Residential, river, schools and other build up land like sport centre, while water bodies denote as polygon, schools and market etc. Arcs and nodes as the components of topological primitives which shows the three objects types are presented in Figure 6, while the ellipse shadowed elementary data that connects them represented by arrows indicates that each element or data type must be classified in a group. An example can be drawn from the arrangements of oil pipelines, water pipelines and roads in line feature which show an arcs beginning and nodes ending which is also characterised by $\mathrm{x}$ and y coordinates. The thematic components of reality as well as semantic relationships existing among the entities are also described by the conceptual phase. 


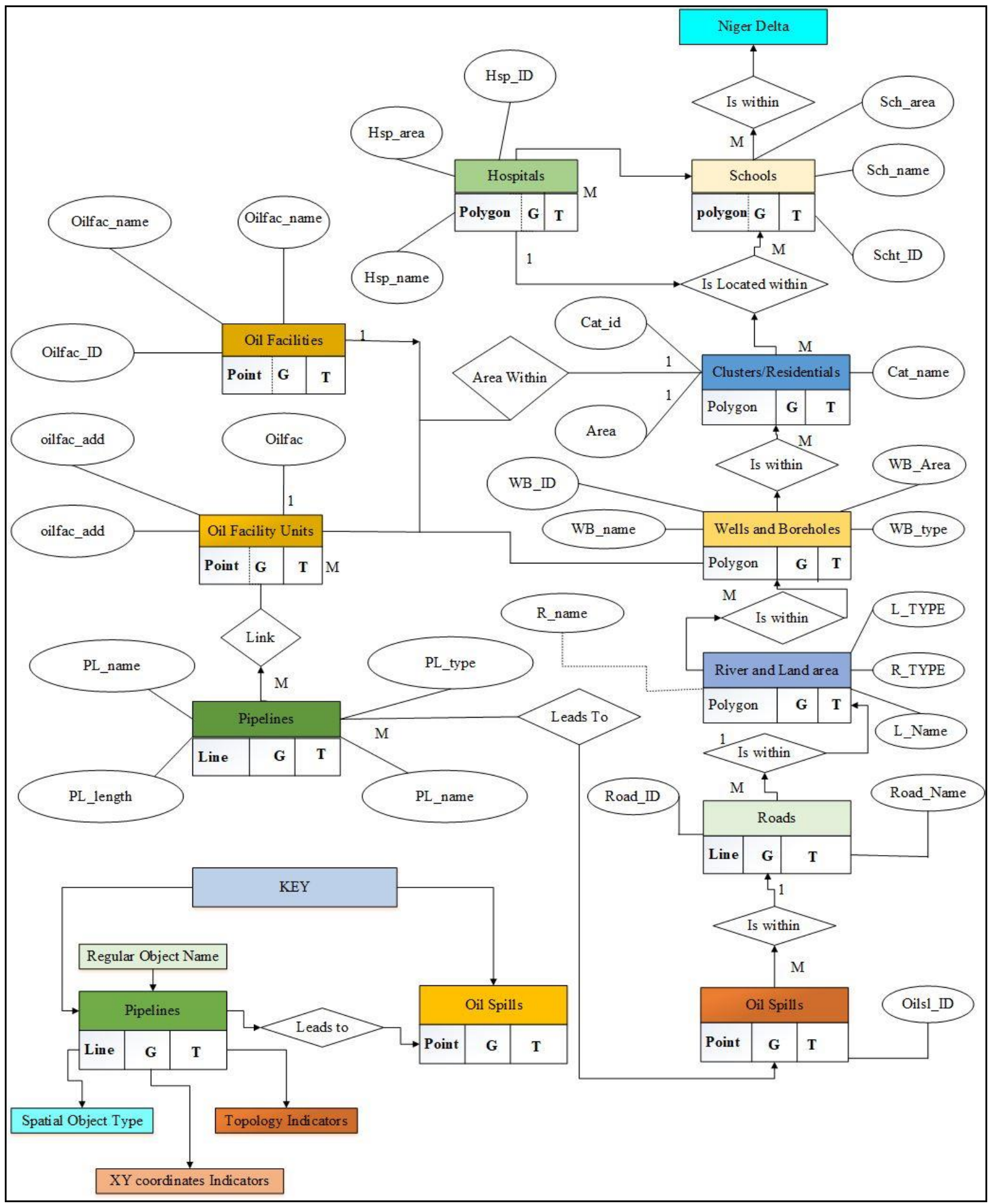

Figure 7. ER Diagram of the study

\subsection{Logical Design}

Logical design involves matching the object types in a conceptual data model to a database model often supported by GIS software, which was initially applied in creating and maintaining the database (Longley et al., 2011). The phase is concern with structuring of basic data relationship and their definition in a defined database system (Teorey et al., 2011). There are basically number of models in logical design which includes network, hierarchical, object-oriented, object relational and geo-relational model. However, in this study relational database model has been adopted which has been translated from conceptual databased model developed. The relational data model was chosen due to it is simplicity in understanding and use as well as it is compatibility with many open source GIS software's. Figure 8 shows the logical database design of oil spill pollution, while Table 4.1 is a master data list showing objects and their relationships. 


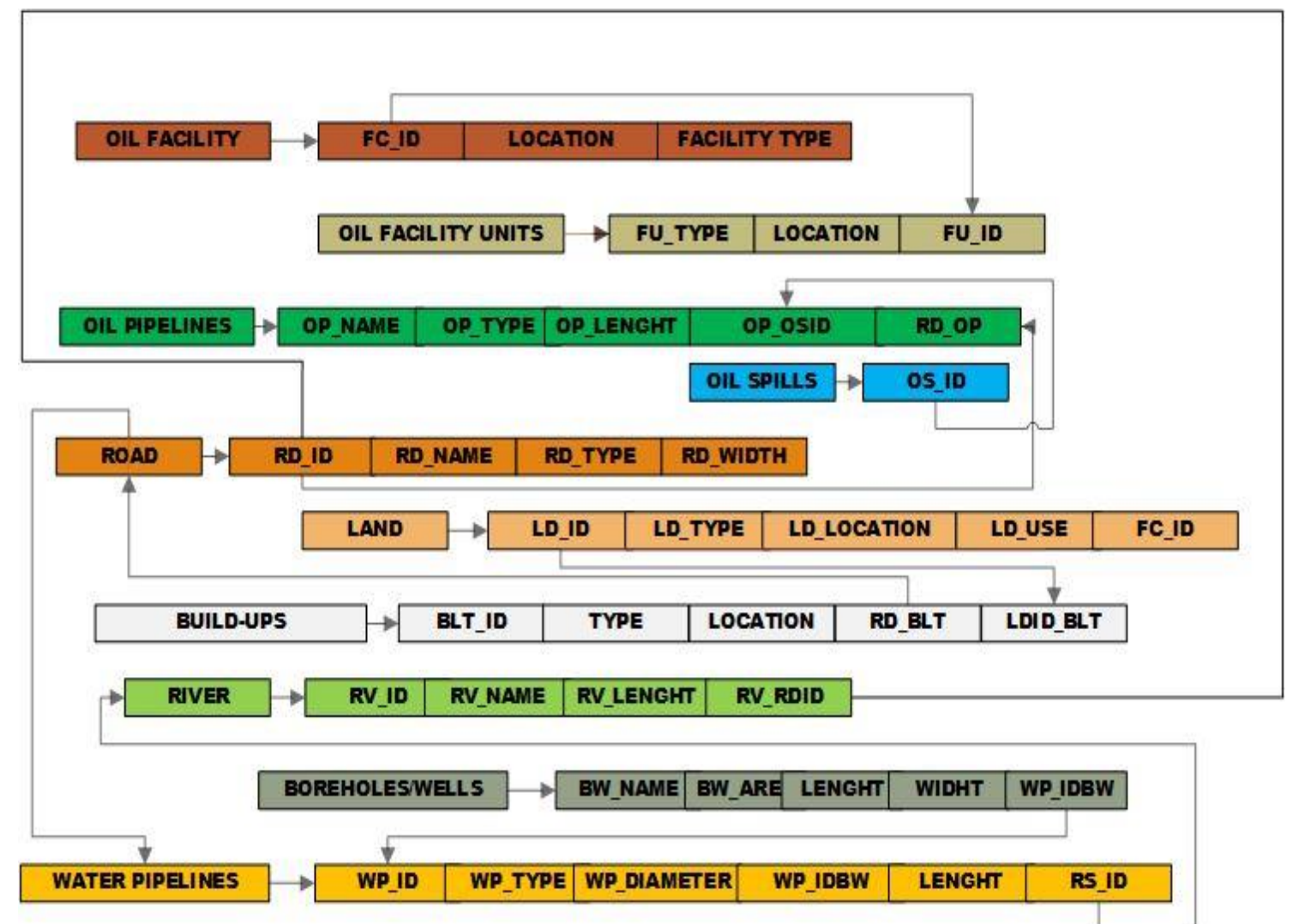

Figure 8. Logical model design of oil spills pollution affecting water quality

Table 4.0 Master Data list (Logical)

\begin{tabular}{|l|l|l|l|l|}
\hline NO & Entity & $\begin{array}{l}\text { Descriptio } \\
\mathbf{n}\end{array}$ & \multicolumn{1}{|c|}{ Attributes } & $\begin{array}{l}\text { Spatial } \\
\text { objects }\end{array}$ \\
\hline 1 & Oil facility & 1 oil facility & $\begin{array}{l}\text { Object ID } \\
\text { Name,address,ID }\end{array}$ & Points \\
\hline 2 & $\begin{array}{l}\text { Oil facility } \\
\text { units }\end{array}$ & $\begin{array}{l}\text { Many oil } \\
\text { facilities }\end{array}$ & $\begin{array}{l}\text { Object ID } \\
\text { Name,address,ID }\end{array}$ & Points \\
\hline 3 & Pipelines & $\begin{array}{l}\text { Lots of } \\
\text { pipelines }\end{array}$ & $\begin{array}{l}\text { Object ID } \\
\text { Name, type, } \\
\text { length, ID }\end{array}$ & Lines \\
\hline 4 & Oil spills & $\begin{array}{l}\text { Many spills } \\
\text { occurrences }\end{array}$ & $\begin{array}{l}\text { Object ID } \\
\text { Name, ID }\end{array}$ & Points \\
\hline & $\begin{array}{l}\text { River \& } \\
\text { Land area }\end{array}$ & $\begin{array}{l}1 \text { River and } \\
\text { lots of Land } \\
\text { areas }\end{array}$ & $\begin{array}{l}\text { Object ID } \\
\text { Name, type, } \\
\text { length, ID }\end{array}$ & Polygon \\
\hline 5 & $\begin{array}{l}\text { Wells \& } \\
\text { boreholes }\end{array}$ & $\begin{array}{l}\text { Lots of } \\
\text { wells \& } \\
\text { boreholes }\end{array}$ & $\begin{array}{l}\text { Object ID } \\
\text { Name, type, } \\
\text { length, ID }\end{array}$ & Polygon \\
\hline 6 & $\begin{array}{l}\text { Residentia } \\
1 \text { areas }\end{array}$ & $\begin{array}{l}\text { Many } \\
\text { residential } \\
\text { areas }\end{array}$ & $\begin{array}{l}\text { Object ID } \\
\text { Area,Name,ID }\end{array}$ & Polygon \\
\hline 7 & $\begin{array}{l}\text { Niger } \\
\text { Delta }\end{array}$ & Region & \multicolumn{2}{|l}{} \\
\hline
\end{tabular}

However, Figure 6 and 8 has been successfully translated in to a relational database structure, Presenting tables of data records and connection to other tables through simple transformation. This transformational rules encompasses mapped entities depicted in Figure 6 and 7 and has been transform in to tables with rows and columns. Also, data definition language was defined by relational schemas and with each relation joining the other through primary foreign key structure. Typical example can be derived from the logical model design were primary key of relation 'land' (LD ID) connects with the foreign key of relation 'Build area' (LD_IDBLT).

\subsection{Physical design}

Physical design is the last stage of the geospatial database design, which involved defining the actual database schema that holds the data values based on the built-in data types of the chosen database management system (DBMS). It is also known as implementation stage, which involves representation of data structure in a format that is compatible with the software. It describes the base relations, file organizations as well as indexes used in order to get access to the data. However, this study used Object-Relational for the DBMS. The physical design for this application based on data definition is shown below. 
Oil facility: \{(F_ID: int, 3) (Name: string, 25) (Class: string, 10) (Width: int, 3) (Status: string, 25)\}

Oil facility Unit: \{(FU_ID: int, 3) (Name: string, 25) (Class: string, 10) (Width: int, 3) (Status: string, 25)\}

Oil pipelines: \{(OP_ID: int, 3) (Name: string, 25) (Class: string, 10) (Width: int, 3) (Status: string, 25)\}

Oil spills: $\left\{\left(\mathrm{OS} \_\right.\right.$ID: int, 3) (Name: string, 25) (Status: string, 25)\}

River: $\{$ (RV_ID: int, 3) (Name: string, 25) (Class: string, 10) (Width: int, 3) (River_type: string, 15)\}

Road: \{(R_ID: int, 3) (Name: string, 25) (Class: string, 10) (Width: int, 3) (Status: string, 25)\}

Land: \{(LD_ID: int, 3) (R_IDLD: int, 3) (Size: int, 6) (Location: string, 35)\}:

Boreholes/wells: $\{($ BW_ID: int, 3) (Location: string, 25) (RD_IDBW: int, 3) (WP_IDBW: int, 3) $\}$

Water Pipeline: $\{($ WP_ID: int, 3) (RD_IDPW: int, 3) (Type: string, 20) $\}$

Figure 9. Physical design application of oil spills pollution affecting water quality

\section{CONCLUSION}

In a developing country like Nigeria, where proactive measures have not been taken in the event of disaster outbreak, designing spatial database would tremendously assist in averting an outbreak of unforeseen disaster. The design pattern of spatial database for oil spill pollution affecting water resources quality in the Niger Delta is expected to proactively improve disaster and emergency management in the region. The database would educate and informed all concerned stakeholders on the need to provide a lasting solution to the insidious nature of oil spills polluting water resources in the area.

The linkages between water resources pollution, disaster and its management would form a platform for proactive management of oil spill pollution in the Niger Delta to effectively and efficiently manage disaster outbreak emanated from oil spill. This database design will form the basis for more research in to the area of water resources pollution in the Niger Delta. This will undoubtedly create more awareness on the importance of preserving and protecting water resources in Nigeria and other developing nations. Furthermore, it is believed that this study would provide a flat form where stakeholders concerned with disaster management in the third world countries would adopt the same template and build upon it in order to maintain spatial data that would be applied on disaster management and resources infrastructure.

The hotspots map resulted from nine years of oil spills pollution in the region is adequate the cause significant damages to the region's water system and to the health of the people living in various communities in the Niger Delta. It is therefore crucial to develop spatial database of oil spill pollution affecting water quality and hotspot maps of areas affected by the spills in order to informed decision makers on the need to protect the environment from the insidious nature of the spills.

\section{ACKNOWLEDGEMENTS}

The authors would like to express their appreciation to Petroleum Technology Development Fund (PTDF) for sponsoring this Reseach and National Oil Spill Detection and Response Agency (NOSDRA) for releasing oil spills data.

\section{REFERENCES}

Abdus-salam, N. and Adekola, F. (2010) 'A Physicochemical Assessment of Water Quality of Oil Producing Areas of', (February 2017).

Achebe, C.H; Nneke, U.C. \& Anisiji, E. . (2012) 'Analysis of Oil Pipeline Failures in the Oil and Gas Industries in the Niger Delta Area of Nigeria', Proceeding of International Multiconference of Engineers and Computer Scientists, Hong Kong, II.

Al-Masree, H.K., (2015) 'Extracting Entity Relationship Diagram (ERD) from relational database schema', International Journal of Database Theory and Application, 8(3), pp. 15-26.

Altan, O. \& Kemper, G., 2010, 'Spatial information for disaster management using examples from Istanbul', in M. Konecny et al. (eds.), Geographic information and cartography for risk and crisis management lecture notes in geoinformation and cartography, pp. 23-37, Springer-Verlag Berlin, Heidelberg. http://dx.doi.org/10.1007/978-3-642-03442-8_2

Adedoyin, B.A. \& Olanrewaju, A.V., 2006, 'Fire Situation in Nigeria', International Forest Fire News 34, 89-93, viewed juner 2019, fromhttp://www.fire.unifreiburg.de/iffn/iffn_34/12IFFN-34-Nigeria.pdf.

Anejionu, O. C. D., Ahiarammunnah, P. A. N. and Nri-ezedi, C. J. (2015) 'Hydrocarbon pollution in the Niger Delta: Geographies of impacts and appraisal of lapses in extant legal framework', Resources Policy. Elsevier, 45, pp. 65-77. 
Awosika, L. . (1995) 'Impacts of global climate change and sea level rise on Coastal resources and energy development in Nigeria. In: Umolu, J.C., (Ed). Global Climate Change: Impact on Energy Development. DAMTECH Nigeria Limited, Nigeria'.

Bagui, S. \& Earp, R. (2011) 'Database design using entityrelationship diagrams, CRC Press, Boca Raton, FL.'

Bank., W. (1995) Defining an environmental management strategy for the Niger Delta. Report prepared by Jasdip Smigh, David Moffat and Olof Linden. Washington D. C.: Industry and Energy operations division, West African Department, World Bank.

Benedek, J., Ciobanu, S. M. and Man, T. C. (2016) 'Hotspots and social background of urban traffic crashes: A case study in Cluj-Napoca (Romania)', Accident Analysis and Prevention. Elsevier Ltd, 87, pp. 117-126.

Benhardsen T., 1992, Geographic Information Systems: An introduction, Third edition pp. 9-17, John Willey \& Sons, Inc.Arendal, Norway.

Birkett, D. \& Jetmarova, H.M., 2014, 'Plan, prepare and safeguard: Water critical infrastructure protection in Australia', Securing Water and Wastewater Systems Protecting Critical Infrastructure 2, 287-313.

Chicas, S. D., Omine, K. and Ford, J. B. (2016) 'Identifying erosion hotspots and assessing communities' perspectives on the drivers, underlying causes and impacts of soil erosion in Toledo's Rio Grande Watershed: Belize', Applied Geography. Elsevier Ltd, 68, pp. 57-67.

Chima, U. D., Adedeji, G. A. and Uloho, K. O. (2013) 'Preliminary assessment of the soil impact of charcoal production in Rivers State, Nigeria', Ethiopian Journal of Environmental Studies and Management, 6(3), pp. 285-293.

Chang, S.E., McDaniels, T., Fox, J., Dhariwal, R. \& Longstaff, H., 2014, 'Toward disasterresilient cities: Characterizing resilience of infrastructure systems with expert judgments', Risk Analysis 34(3), 416-434.

Currim, S., Ram, S., Durcikova, A. \& Currim, F. (2014) 'Using a knowledge learning framework to predict errors in database design', Information Systems 40, 11-31.'

Davidson, L. \& Moss, J.M., 2012, Relational database design and implementation,A press, viewed January 2013, from https://books.google.co.za/books?id=Rltj3OGrp_UC\&pg=PA56 $3 \& \operatorname{lpg}=$ PA563\&dq

Ebeku, K. S. A. (2005) 'Oil and the Niger Delta People in International Law. Resource Rights, Environmental and Equity Issues, OGEL Special Study', 5.

Egberongbe, F., Nwilo, P. and Badejo, O. (2006) 'Oil Spill Disaster Monitoring along Nigerian Coastline', 5th FIG Regional Conference, pp. 8-11.

Elias, P. \& Omojola, A., 2015, 'Case study: The challenges of climate change for Lagos, Nigeria', Current Opinion in Environmental Sustainability 13, 74-78.
Eludoyin, O. M., Adelekan, I. O., Webster, R., \& Eludoyin, A. O. (2014). Air temperature, relative humidity, climate regionalization and thermal comfort of Nigeria. International JournalofClimatology,34(6),2000-2018.

https://doi.org/10.1002/joc.3817

Ezekwe, C. I. and Utong, I. C. (2017) 'Hydrocarbon Pollution and Potential Ecological Risk of Heavy Metals in the Sediments of the Oturuba Creek, Niger Delta, Nigeria', Journal of Environmental Geography, 10(2), pp. 1-10.

Faturechi, R. \& Miller-Hooks, E., 2015, 'Measuring the performance of transportation infrastructure systems in disasters: A comprehensive review', Journal of Infrastructure System 21(1), 04014025.

Gabriel, A. O. I. (no date) 'Women in the Niger Delta: Environmental Issues and Challenges in the Third Millennium Ecology and Women's Economic Activities Environmental Issues and Women's Economic Activities'.

Getta, J.R., 1993, 'Translation of extended entity-relationship database model into object-oriented database model', in Hsiao et al. (eds.), Interoperable Database Systems (DS-5) (A-25) 87100, Elsevier Science Publishers, B.V.,Pennsylvania, USA..

Harcourt, P. (2014) 'Petroleum Hydrocarbon Contamination of the Environment: A Case Study’, 6(1), pp. 67-79.

Hochrainer-Stigler, S., Mechler, R. \& Mochizuki, J., 2015, 'A risk management tool for tackling country-wide contingent disasters: A case study on Madagascar', Environmental Modelling \& Software 72, 44-55

Hiscock, K. M. and Grischek, T. (2002) 'Attenuation of groundwater pollution by bank filtration', 266(November 2000), pp. 139-144.

Hooper, R.J., Fitzsimmon, R.J., Grant, N., Vendeville, B. . (2002) 'The role of deformation in controlling depositional patterns in the south-central Niger Delta, West Africa', Journal of Structural Geology, 24(4), pp. 847-859.

Hsiao, D.K., Neuhold, E.J. \& Sacks-Davis, R. (eds.), 2014, Interoperable Database Systems (DS-5): Proceedings of the IFIP WG2. 6 Database Semantics Conference on Interoperable Database Systems (DS-5) Lorne, Victoria, Australia, 16-20 November, 1992, Elsevier, Pennsylvania, USA.

Ipingbemi, O. (2009) 'Socio-economic implications and environmental effects of oil spillage in some communities in the Niger delta', Journal of Integrative Environmental Sciences, 6(1), pp. 7-23.

IUCN (International Union for the Conservation of Nature) (no date) 'A Guide to the Convention to the Biological Diversity', Environmental Policy and Law Pape, (30).

Kadafa, A. A. (2012) 'Oil Exploration and Spillage in the Niger Delta of Nigeria', Civil and Environmental Research, 2(3), pp. 38-51.

Kadivar, M. (2015) 'Entity relationshi p diagra m approac h t o defini ng cyber-attacks' , A Doctoral dissertation, Carleton University.' 
Kerle, N.W. \& Kufoniyi, O., 2005, 'Towards innovative problem solving methodologies for less developed countries in Asia', 26th Asian Conference on Remote Sensing, Hanou, pp. $1-6$

Kponee, K. Z., Chiger, A., Kakulu, I. I., Vorhees, D. and Heiger-Bernays, W. (2015) 'Petroleum contaminated water and health symptoms: a cross-sectional pilot study in a rural Nigerian community', Environmental Health: A Global Access Science Source. Environmental Health, 14(1), pp. 1-8.

Kuenzer, C., van Beijma, S., Gessner, U. and Dech, S. (2014) 'Land surface dynamics and environmental challenges of the Niger Delta, Africa: Remote sensing-based analyses spanning three decades (1986-2013)', Applied Geography. Elsevier Ltd, 53, pp. 354-368.

Kuo, P. F., Lord, D. and Walden, T. D. (2013) 'Using geographical information systems to organize police patrol routes effectively by grouping hotspots of crash and crime data', Journal of Transport Geography. Elsevier Ltd, 30, pp. 138148

Kufoniyi, O. \& Akinyede, J., 2004, 'Mainstreaming geospatial information in National Development in Nigeria', IAPRS XXXV (Part B4), 293-298.

Kwasinski, A., 2014, 'Field technical surveys: An essential tool for improving critical infrastructure and lifeline systems resiliency to disasters', Proceedings of IEEE 2014 Global Humanitarian Technology Conference(GHTC) 2014 IEEE, 7875. IEEE

Lindén, O. and Pålsson, J. (2013) 'Oil contamination in ogoniland, Niger delta’, Ambio, 42(6), pp. 685-701.

Longley, P. A., Cheshire, J. A. and Mateos, P. (2011) 'Creating a regional geography of Britain through the spatial analysis of surnames', Geoforum. Elsevier Ltd, 42(4), pp. 506-516.

M.K.Ukoli (2005) 'Environmental Factors in the Management of the Oil and Gas Industry in Nigeria'.

Mahboubi, P., Parkes, M., Stephen, C. and Chan, H. M. (2015) 'Using expert informed GIS to locate important marine socialecological hotspots', Journal of Environmental Management. Elsevier Ltd, 160, pp. 342-352.

Manfré, L.A., Hirata, E., Silva, J.B., Shinohara, E.J., Giannotti, M.A., Larocca, A.C. \& Quintanilha, J.A., 2012, 'An analysis of geospatial technologies for risk and natural disaster management', ISPRS International Journal of Geo-Information $1,166-185$

Mittelstadt, S., Wang, X., Eaglin, T., Thom, D., Keim, D., Tolone, W. et al., 2015, 'An integrated in-situ approach to impacts from natural disasters on critical infrastructures', Proceeding of the 2015 48th Hawaii International Conference on System Sciences (HICSS) held at Kauai, Hi, IEEE, pp. $1118-1127$

Mustafa, S., A Bahar, ZA Aziz, S. S. (2014) 'Review of the Role of Analytical Modelling Methods in Riverbank Filtration System', Jurnal Teknologi, 71(1).
Macal, C.M. \& North, M.J., 2006, 'Introduction to agent-based modelling and simulation. A presentation made at MCS LANS informal seminar', viewed June 2019, from www.mcs.anl.gov/leyffer/listn/slide-06/macanorth.pdf

Nduka, J. K. and Orisakwe, O. E. (2011) 'Water-quality issues in the Niger Delta of Nigeria: A look at heavy metal levels and some physicochemical properties', Environmental Science and Pollution Research, 18(2), pp. 237-246.

Nicolini, J., Pereira, B. F., Pillon, C. N., MacHado, V. G., Lopes, W. A., De Andrade, J. B. and Mangrich, A. S. (2011) 'Characterization of Brazilian oil shale byproducts planned for use as soil conditioners for food and agro-energy production', Journal of Analytical and Applied Pyrolysis, 90(2), pp. 112117.

Nwaichi, E. O. and Ntorgbo, S. A. (2016) 'Assessment of PAHs levels in some fish and seafood from different coastal waters in the Niger Delta', Toxicology Reports. Elsevier Ireland Ltd, 3, pp. 167-172.

Ogboghodo, I. and Iruaga, E. (2004) 'An assessment of the effects of crude oil pollution on soil properties, germination and growth of maize (Zea mays) using two crude types-Forcados light and Escravos', Environmental Monitoring ..., (February 2014).

Olowu, D., 2010, 'The Hyogo framework for action and its implications for disaster management and reduction in Africa', JAMBA: Journal of Disaster Risk Studies 3(1), 303-320.

Onwuka, S., Ikekpeazu, F. \& Muo, A., 2015, 'Analyses of the effectiveness of the various measures employed by people in the control of flooding in six communities in Awka Anambra State of Nigeria', Civil and Environmental Research 7(2), 149-167

Osuji, L. C. and Onojake, C. M. (2004) 'Trace Heavy Metals Associated with Crude Oil: A Case Study of Ebocha-8 OilSpill-Polluted Site in Niger Delta, Nigeria of normal geological phenomena such as ore formation, weathering of rocks, and excessive release of these metals into the environmen', 1, pp. $1708-1715$

Osuji, L. C., \& Nwoye, I. (2007). An appraisal of the impact of petroleum hydrocarbons on soil fertility : the Owaza experience. African Journal of Agricultural Research, 2(July), 318-324

O'Sullivan, D. \& Unwin, J.D., 2014, Geographic information analysis, 2nd edn., John Wiley \& Sons, Hoboken, NJ.

Obi, E.U., 2006, 'Public safety and emergency response in Nigeria: A systematic approach', viewed June 2019, from http://www.dawodu.com/obi7.htm

Olowu, D., 2010, 'The Hyogo framework for action and its implications for disaster management and reduction in Africa', JAMBA: Journal of Disaster Risk Studies 3(1), 303-320

Ouyang, M., 2015, 'Review on modeling and simulation of interdependent critical systems', Reliability Engineering \& System Safety 121, 43-60

Pederson, P., Dudenhoeffer, D., Hartley, S. \& Permann, M., 2006, 'Critical infrastructure interdependency modeling: A 
survey of U.S. and international research', Prepared for the technical support working group under work for others agreement 05734, Under DOE Idaho Operations Office, Contract DE-AC07-05ID14517, Idaho National Library, pp. 120 .

Phil-Eze, P. O. and Okoro, I. C. (2009) 'Sustainable biodiversity conservation in the Niger Delta: A practical approach to conservation site selection', Biodiversity and Conservation, 18(5), pp. 1247-1257.

Ray, C. and Shamrukh, M. (no date) Riverbank Filtration for $A B 3$.

Rigaux, P., School, I.M. \& Voisand, A. (2002) 'Spatial databases with application to GIS', Morgan Kaufmann Publishers, Pennsylvania, USA., pp. 6-28.

Salem, F. (2001) 'Hyperspectral Image Analysis for Oil Spill Mitigation', Science, (November), pp. 5-9.

Samuel, J.K., Ayeni, B., Adebayo, H.O. \& Adagbasa, G.E., 2014, 'A geospatial analysis of flood risks and vulnerability in Ogun-Osun River Basin, Nigeri In: Singh et al (eds.) landscape ecology and water management', Proceeding of IGU Rohtak Conference, vol. 2, Advances in Geographical and Environmental Sciences, Springer Japan, 307-320. http://dx.doi.org/10.1007/978-4-431-54871-3_22

Teorey, T.J., Lightstone, S.S., Nadeau, T. \& Jagadish, H.V. (2011) 'Database modeling and design: Logical design Fifth Edition, Morgan Kaufmann Publishers, MA, USA.'

Thalheim, B. (2013) 'Entity-relationship modeling: Foundations of database technology, Springer-VerlagBerlin NY, USA..'

Toroczkai, Z. \& Eubank, S., 2005, 'Agent-based modeling as a decision-making tool', The Bridge 35(4), 1-12.

Tolulope, A. . (2004) 'Oil Exploration and Environmental Degradation: the Nigerian Experience.', International Society for Environmental Information Science, Internatio.

Tunde Imoobe, B. O. and Iroro, T. (2009) 'Ecological Restoration of Oil Spill Sites in the Niger Delta, Nigeria', Journal of Sustainable Development in Africa, 11(2), pp. 5465 .

Trucco, P. \& Petrenj, B., 2015, 'An ontology-based approach to vulnerability and interdependency modelling for critical infrastructure systems', in T. Nowakowski et al. (eds.), Safety and reliability: Methodology and application, pp. 49-56, Proceedings of the European Safety and Reliability Conference, Esrel 2014, Wroclaw, Poland, 14-18 September 2014, CRC, London, UK. Umanath, N. \& Scamell, R. (2014) 'Data modeling and database design, 2nd edn., Cengage Learning, Boston, MA.'

Xie, Z. and Yan, J. (2013) 'Detecting traffic accident clusters with network kernel density estimation and local spatial statistics: An integrated approach', Journal of Transport Geography. Elsevier Ltd, 31, pp. 64-71.

Yusta, J.M., Covrea, G.J. \& Local-Arantegun, R., 2011, 'Methodologies and applications for critical infrastructure protection: State-of-the-art', Energy Policy 39, 6100-6119.

Yakubu, O. (2017) 'Addressing Environmental Health Problems in Ogoniland through Implementation of United Nations Environment Program Recommendations: Environmental Management Strategies', Environments, 4(2), p. 28.

Zevenbergen, J., Kerle, N. \& Tuladhar, A., 2013, 'Spatial Information for assessing land issues in disaster risk management', An FIG 2013 Conference Publication, viewed August2014,fromhttp://www.fig.net/pub/fig2013/ppt/ts07a/TS0 7A_zevenberge_kerle_et_al_6607ppt.pdf

Revised August 2019 